\title{
The Role of Theory in Ethnographic Research
}

\section{Citation}

Wilson, William Julius, and Anmol Chaddha. 2010. The Role of Theory in Ethnographic Research. Ethnography 10(4): 549-564.

\section{Published Version}

http://dx.doi.org/10.1177/1466138109347009

\section{Permanent link}

http://nrs.harvard.edu/urn-3:HUL.InstRepos:4778477

\section{Terms of Use}

This article was downloaded from Harvard University's DASH repository, and is made available under the terms and conditions applicable to Open Access Policy Articles, as set forth at http:// nrs.harvard.edu/urn-3:HUL.InstRepos:dash.current.terms-of-use\#OAP

\section{Share Your Story}

The Harvard community has made this article openly available.

Please share how this access benefits you. Submit a story.

Accessibility 


\title{
The Role of Theory in Ethnographic Research
}

\author{
William Julius Wilson and Anmol Chaddha \\ Harvard University
}

The ethnographic method examines behavior that takes place within specific social situations, including behavior that is shaped and constrained by these situations, plus people's understanding and interpretation of their experiences. A full appreciation of ethnography's contribution to social science would entail a critical examination of its methodology within both the context of discovery and the context of validation. In the logic of social scientific inquiry, the former is concerned with the way in which fruitful concepts, hypotheses and theories are discovered, whereas the context of validation is concerned with the evaluation of the products of social science and therefore with clearly spelling out the evaluative criteria.

In recent years, ethnography has been discussed both within the context of discovery and the context of validation. In the context of discovery it is generally acknowledged that ethnography enables social scientists to uncover relationships that have not been explicitly spelled out in theoretical formulations. These discoveries often lead to the formation of hypotheses that provide direction for further research 
either involving smaller ethnographic samples or with larger and more representative samples. In the context of validation ethnographic data can be used to test, advance or explain empirical assumptions. Ideally, these assumptions are derived from theoretical arguments. In the absence of theory, the use of ethnography in the context of validation is problematic, as we shall soon see.

We emphasize this distinction because a number of people have maintained that the best way to integrate ethnographic and quantitative research is to use the former in the context of discovery and the latter in the context of validation. In other words, it is argued that ethnography ought to be used to generate hypotheses that could then be tested with quantitative data. Accordingly, the major objection to using ethnographic research in the context of validation is the inherent difficulty of generating a sample representative of a larger population. However, there is another type of sampling crucial to theory testing, and very appropriate for ethnographic research, known as theoretical sampling, that is the selection of natural cases that include the necessary conditions for the application of theoretical arguments--arguments that steer the research and are used to interpret the findings (Willer, 1967). For example, assume a researcher is attempting to test Wilson's theory of the social transformation of the inner city, a theory that includes a number of the 
key hypotheses on 'concentration effects'-the effects of living in highly concentrated poverty areas (Wilson, 1987). One of these hypotheses states that individuals living in extreme poverty areas are much less likely to be tied into the job information network system than those living in marginal poverty areas. This hypothesis could be tested by a participant observer who selects a neighborhood that represents an extreme poverty area and one that represents a marginal poverty area, and who observes patterns of work-related interactions in each neighborhood over an extended period of time. Some scholars may question the degree of rigor involved in testing such a hypothesis with participant observation techniques, but this approach is clearly consistent with the logic of validation, and it represents a deductive process whereby prior theoretically derived arguments are tested with ethnography data.

However, there is another way in which theory plays a role in ethnographic research that is inductive, not deductive. Here theoretical insights inform the interpretation of data uncovered in the context of discovery. In the process the ethnographer integrates new empirical findings with theoretical arguments not in the sense of testing prior theoretically driven hypotheses but in using his or her theoretical knowledge to make sense of the new data uncovered in the field research. 
Finally, there are some ethnographic studies that incorporate theory into research that can be described as neither purely deductive nor inductive, but reflect elements of both. In other words, there are studies that start out with a deductive theory and end up generating theoretical arguments in an inductive process that integrates old theoretically derived ideas with new and unanticipated theoretical arguments based on data uncovered in the field research.

We will more closely examine the role of theory in ethnographic studies in these various forms by critically reflecting on issues raised in an article that motivated the writing of this paper, namely Loic Wacquant's review essay in the American Journal of Sociology, 'Scrutinizing the Street: Poverty, Morality, and the Pitfalls of Urban Ethnography' (Wacquant, 2004). This publication created a firestorm of controversy because of Wacquant's harsh and contentious critique of the widely read urban ethnographies by Elijah Anderson (1999), Mitchell Duneire (1999) and Katherine Newman (1999).

Although Wacquant's long review essay raised a number of important issues concerning the role of theory in ethnographic research, unfortunately his arguments failed to engender a serious discussion among scholars, including urban poverty researchers, on this important subject, a discussion he had hoped his review would ultimately generate. Why? Mainly because the dismissive tone of his 
review and his inflammatory arguments distracted many readers from focusing on his most fundamental point-the separation of ethnography from theory.

While Wacquant raises a wide-ranging set of issues in his review essay, the discussion to follow focuses only on the arguments concerning the role of theory in ethnographic research. We will examine and critically assess both Wacquant's critique of the disjunction of ethnography from theory and the authors' respective rejoinders, and, in the process, raise a few critical issues about inductive and deductive theory in ethnographic research, and reflect on problems when ethnography is devoid of theory.

\section{Wacquant's View of the Disjunction of Ethnography from}

\section{Theory}

Wacquant points to several important shortcomings that he sees as common across these three studies and reflective of a troubling pattern in recent urban ethnographic research. The three ethnographies are marked, he argues, by an inappropriate disconnect between theory and observation, which can lead to different, but equally troubling, analytical weaknesses in ethnographic research: the researcher may lack critical distance from the subjects and merely report, without analyzing, their perspectives; the analyst may shape 
observations to fit preconceived notions and make claims that are not well supported by the data; or the research may be organized according to the terms of public discourse around certain social issues, instead of applying the analytical lens of social science. Wacquant suggests that the poor fit between theory and observation in these studies facilitates the scholars' 'naïve acceptance of ordinary categories of perception as categories of analysis,' as moralistic accounts replace social analysis (Wacquant, 2002: 1470).

Wacquant argues that if theoretical control is not exercised at each step in the process of designing and implementing an ethnographic study-as is true of ever other method of social observation and analysis-ordinary notions based on common sense will emerge to 'fill the gap and steer crucial decisions on how to characterize, parse, and depict the object at hand' (Wacquant, 2002: 1524). Accordingly, distinctive ethnography and powerful theory are complementary not antithetical and 'the best strategy to strengthen the former is to bolster the latter' (Wacquant, 2002: 1524).

In Code of the Street (1999), Anderson conducts ethnographic research to examine the social order of a community in inner city Philadelphia. He argues that activity and behavior in the neighborhood are characterized by one of two 'codes.' The 'code of the street' is one that places highest value on interpersonal respect and makes regular 
use of the threat of physical violence to assert one's self. While outsiders commonly stereotype all inner-city residents as acting in accordance with this code, many residents in fact follow the 'decent' code, which reflects middle-class values, personal responsibility, and participation in the mainstream economy instead of illegitimate activities. In the context of these conflicting codes, community residents develop the ability to regularly switch between codes to adapt to different situations.

Wacquant presents several specific criticisms related to the role of theory in Code of the Street. He criticizes Anderson for approaching the division between 'street' and 'decent' as substantive and fixed social categories in the community, thereby inappropriately accepting what Wacquant suggests are 'folk concepts' as analytical categories. Specifically, he charges that 'transmuting folk notions that residents use to make sense of their everyday world into mutually exclusive populations prevents Anderson from analyzing the dynamic contest of categorization out of which the distinction between "street" and "decent" arises and how this contest affects individual conduct and group formation. For it leaves unexamined the social mechanisms and paths whereby different persons drift toward this or that end of the spectrum, and what facilitates or hinders their sliding alongside it' (Wacquant, 2002: 1488). 
Next, Wacquant argues that because Anderson fails to employ a theoretical framework that incorporates the stratification of social positions within the community, he cannot relate the moral distinctions of the 'street' and 'decent' codes to a system of internal social stratification. Rather than representing exclusive groups defined by a moral or cultural orientation, the street-decent division may actually describe groups who occupy different social positions with respect to the mainstream economy, and make use of the 'street' and 'decent' cultural orientations to attach meaning to their divergent standing.

He also criticizes Anderson for not providing a theoretical explanation of how a code should be understood as influencing social action. Wacquant asks: 'But what exactly is a code, where does the "code of the street" come from and how does it actually generate particular behaviors? One would expect that Anderson's book would elucidate these issues, but the more one reads the more muddled they seem to become ... If the code is both a cultural template that molds behavior and that behavior itself, the argument becomes circular' (Wacquant 2002: 1491). Here, as with the discussion of urban ethnography more generally, Wacquant points to the limitations of ethnographic research to provide adequate explanations of social mechanisms if it is insufficiently integrated with theoretical concerns. 
In Sidewalk (1999), Duneier conducts an ethnographic study of street vendors in New York City to analyze the interplay of moral behavior, public space, and safety. With respect to the discussion of theory in ethnography, Wacquant argues that Duneier was not led by an interest in addressing specific sociological questions in pursuing his research. Instead, he suggests that Duneier projected his interests in morality onto a site to which he had access, without consideration of its theoretical significance. Suspecting that Duneier is motivated to portray his informants in an unrealistically positive light, Wacquant charges that he 'takes the statements of his informants at face value and conflates "vocabularies of motives" with social mechanisms, the reasons invoked by vendors to make sense of their actions with the causes that actually govern them' (Wacquant 2002: 1480-81). As is the case with Anderson, Duneier is accused of accepting the perspectives of informants uncritically and as self-evident explanations of their behavior, which in Wacquant's view does not pass muster as acceptable grounds on which to base sociological explanations.

Duneier does engage more explicitly in theoretically informed debates when he seeks to assess theories that link physical and social disorder to safety concerns in public spaces. Here, however, Wacquant faults him for arguing that the street vendors actually 
enhance safety on the street, since the claim is not substantiated by data presented in the study.

In No Shame in My Game, Newman (1999) presents ethnographic research on low-wage, service sector workers in Harlem, against the backdrop of high rates of inner city joblessness. Despite dim labor market prospects for inner city workers, Newman documents the experiences of those residents who do not turn to the street economy, but instead remain committed to the challenging pursuit of an economic livelihood in formal sector employment.

In Wacquant's view, Newman places disproportionate emphasis on the moral orientation of these workers in explaining their continued engagement with the formal economy, even though they have limited opportunities for earning decent wages or advancing to higher positions. Wacquant criticizes Newman for attributing their actions to their commitment to an outlook that values a 'mainstream' work ethic and self-sufficiency over idleness or dependency, and in the process inappropriately praising their virtuosity and heroism.

Wacquant's general critique of Newman is rooted in his view of the disjuncture between theory and ethnography in her study. First, he argues that she employs an atheoretical conception of 'culture' that is used in her study in its essentialist variant (as in a 'mainstream culture' that values work and individualism) that is limited in 
explanatory power. This gives rise to a normative judgment of the virtue of her subjects and leads Newman to associate their behavior with their cultural or moral orientation, without incorporating other theoretically informed explanations of their actions. To wit, Wacquant argues that pointing to the 'character, resolve, and responsibility' of the workers is not engaging in sociological analysis, but making a moralistic pronouncement about the strategies they pursue in their particular circumstances.

Second, he suggests that Newman makes use of a limited theoretical conception of choices and constraints and how they influence her subjects. In Wacquant's view, by distinguishing ghetto residents who work in the mainstream economy and explaining their actions as the result of decisions they made based on a 'mainstream' work ethic, Newman's analysis is based on a faulty assumption of the freedom of ghetto residents to choose between positions in and outside of the formal labor market. He argues, 'Couching these alternative paths in (and out of) the local socioeconomic structure in terms of individual volition and discretion thwarts the analysis of the mechanisms and conditions under which differently positioned youth follow this or that circuit and with what consequences' (Wacquant. 2002: 1512). 
Given the breadth of the criticisms issued by Wacquant, the authors raise numerous objections in defense of their work, beyond the specific concerns about theory. In keeping with the focus of this discussion, we take account only of those comments in the authors' rejoinders to Wacquant that respond to his points about the role of theory in ethnography.

Among the authors, Anderson most directly engages with Wacquant's criticisms about the disconnect between theory and observation in Code of the Street. In the context of the failure of mainstream institutions to establish civil order in inner city communities, Anderson argues that residents have had to develop informal strategies that rely on 'street justice' and are oriented around the 'street code.' The breakdown of 'civil law', as Anderson puts it, contributes to the observed high rates of urban violence, exacerbated by the structural conditions of institutionalized racism, joblessness, and alienation.

Anderson fundamentally rejects what he interprets as Wacquant's 'peculiar view of the role of social theory in ethnographic work. His view demands that the ethnographer begin with a rigid commitment to a theory. The ethnographer must then subordinate the cultural complexity he or she finds in the field to that theory' (Anderson, 2002: 1534). 
In Anderson's view, Wacquant is wedded to a 'top-down' approach to ethnography that stubbornly views micro-level actions as necessarily reflective of macro-level structural factors and the organization of power in society. In contrast, Anderson describes his own, more inductive conception of ethnographic research. In this approach, an ethnographer should 'be familiar with and edified by the various sociological theories at hand' and use his sociological knowledge, in combination with local knowledge gained from the site, to formulate the analytical questions that guide the research. The ethnographer then uses cases gleaned from field notes to test and refine his hypotheses in an effort to build a general argument.

Their diverging approaches to the use of theory in ethnographic research is evident in the discussion of Wacquant's claim that Anderson fails account for internal social stratification in the inner city to explain the emergence and salience of the street-decent dichotomy, and instead accepts these 'folk concepts' as analytical categories. Wacquant argues: 'Had he started from a systematic map of social differentiation inside the ghetto, he would have found that what he depicts as the coexistence of two codes that seem to float up above the social structure is in fact' a division between inner city residents that corresponds to their varying social positions, particularly with regard to their relationship to mainstream institutions (Wacquant, 
2002: 1500). In this view, a theoretical framework that accounts for internal social stratification would inform an interpretation of the ethnographic data and point to an underlying mechanism or social process that would not otherwise be evident by drawing only from what the researcher himself finds in the field. Reflecting the inductive approach he described earlier, Anderson responds: 'I did not start with a map [of social differentiation in the ghetto] because there is no map and none is required. I found what I found by doing field work and involving myself in the lives of people living the reality of the inner city every day' (Anderson 2002: 1543).

In his response, with regard to the role of theory, Duneier rejects Wacquant's central criticism that he was not led to his research by sociological concerns in the questions examined and the research site. He explains, 'A core issue of my agenda was to understand the ways in which "moral" behavior and "decency" are and are not constructed within settings seemingly unfavorable to such behavior' (Duneier, 2002: 1551). Duneier also describes Sidewalk as engaging with theories about public space and safety popularized by Jane Jacobs (1961), who believed that increased activity corresponds with more 'eyes on the street,' which serves a regulating function that militates against anti-social behavior.

Related to Anderson's explanation of his inductive approach, 
Duneier explains, 'My approach is not strictly inductive or deductive: I engage a variety of theoretical/sociological questions, some of which I brought to the site from the beginning, some of which I discovered through various routes as I worked in the site' (Duneier, 2002: 1566). Like Anderson, Duneier also criticizes Wacquant's application of theory in ethnography as deterministic and overly committed to macro-level explanations without leaving adequate room for microlevel specificity and nuance. Duneier argues, 'The ethnographer who allows theory to dominate data and who twists perception to cover the facts makes a farce out of otherwise careful work. There is a middle ground: to try to grasp the connections between individual lives and the macro-forces at every turn, while acknowledging one's uncertainty when one cannot be sure how those forces come to bear on individual lives' (Duneier, 1999: 334; quoted in Duneier, 2002: 1572).

With regard to the role of theory, Newman rejects Wacquant's characterization of her book, No Shame in My Game (1999), as primarily a journalistic glorification of the working poor that sings praise to their mainstream cultural values, while seemingly distinguishing them as more deserving than their peers who are not involved in the mainstream economy as low-wage workers. Newman explains that by focusing on the working poor in the inner city, she engages with earlier theories of the urban poor that emphasized their 
detachment from the labor force, their disconnection from 'mainstream' behavior, and the lack of role models that promote 'mainstream' values. 'The fundamental purpose of No Shame in My Game,' Newman writes, 'was to hold these conclusions up to the light of ethnographic research among low-wage workers and unemployed job seekers in Harlem ... The genesis then of No Shame was a confrontation with the central tenets of underclass theory" (Newman 2002: 1578).

Newman also offers a theoretical justification for her selection of places of employment as her field site, since these are the sites of interaction between the middle-class and the urban working class. Among the specific claims she rebuts is Wacquant's argument that she exclusively attributes the decision of workers to engage in formal employment to the strength of their values without taking into account material conditions that would influence their course of action. While Wacquant criticizes her for simply replacing the stereotype of an idle ghetto resident dependent on state support with that of a virtuous low-wage worker, Newman offers a defense of looking beyond academic debates to public discourse on issues of urban poverty. She argues, 'Wacquant can rail that moral judgment has no place in sociology, or that books like mine should not address the moral portraits that exist about the poor, but that is just head-in-the-sand 
thinking,' since popular discussions of the urban poor are rife with unsympathetic moral judgment (Newman, 2002: 1591).

\section{Reflections on the Debate Concerning the Separation of Ethnography From Theory}

In examining the exchange between Wacquant and these three authors, we come back to our earlier discussion of the role of theory in ethnographic research. Few people would disagree with the view that theoretical issues ought to inform one's interpretation of ethnographic data. There are many examples of theoretically sophisticated ethnography such as Herbert Gans', The Urban Villagers (1962), Gerald Suttles', The Social Order of the Slums (1970), Ulf Hannerz's, Soulside (1969) Michael Burawoy's Manufacturing Consent (1979), Paul Willis', Learning to Labor (1981), and Mario Small's, Viva Victoria (2004). The issue is how theory is used in ethnographic studies. This is where the debate ought to begin and why we need to seriously consider Wacquant's argument about the disconnect between recent urban ethnography and theory in that debate. If theory is to play a role in ethnography, should it be largely deductive, as Wacquant seems to suggest, or inductive as reflected in Anderson's work? Or should theory in ethnographic research be both inductive and deductive, as suggested in the work of Duneier? 
In Anderson response to Wacquant's critique, he makes a strong case for the inductive theoretical approach. Anderson states: 'the ethnographer should enter the field armed with a certain sociological sophistication.' For example, he points out that his own fieldwork tends to be inductive and that he has been influenced by theoretical work of scholars like Simmel, DuBois, Weber, Durkheim, Mead, Blumer, Goffman, and Becker. Anderson argues that, armed with this theoretical knowledge, he does indeed enter the field with a theoretical perspective. And as his fieldwork proceeds this perspective helps him to 'formulate questions concerning the social organization of the subjects and their settings' (Anderson, 2002: 1536). And he argues persuasively that 'the most penetrating ethnographic questions often results from a fusion of concern that reflect both the ethnographers engagement of the social setting as well as his or her own sociological orientation' (Anderson, 2002: 1536-37).

In response to Wacquant's criticism that he fails to apply a systematic social map to understand how street-decent categories function in relation to the social positions of ghetto residents, Anderson responds that he does not begin with a systemic map because "there is no systemic map" and none is required. However, one could raise a legitimate question: How could there not be an arrangement of social positions in the community? An answer to this 
question is important because it relates to what Wacquant means by theoretically informed research. Anderson seems to feel that the researcher can just figure out what you need to know "inductively" in the field. He mentions of course his familiarity with the classical theorists (e.g., Durkheim, Weber, Simmel, and others) but since he does not make explicit how these theories informs his research in the book, Wacquant's was not unjustified in raising the issue of the extent to which theory guides his interpretation of the data.

However, it is important to point out that Wacquant is not criticizing Anderson's theoretically-informed approach, per se. He has a problem with Anderson's reliance on folk concepts (i.e. streetdecent) in his explanations. Anderson defends his use of folk concepts, since that is what he learned from the field. Anderson incorrectly claims that Wacquant dismisses folk concepts. In fact, Wacquant says they can be descriptively useful, but he questions using them as the basis of analytical/theoretical explanations. We feel, in this connection, that Anderson's uses 'street' and 'decent' inconsistently as categories in the book. For one, they are better described as cultural frames though which the residents make sense of their world, their actions, and the behavior of others. However, through much of the book Anderson describes 'street' and 'decent' as fluid categories between which the same person switches, and in other 
cases as exclusive categories to which families belong. This weakens the analytic power of these concepts and leads Wacquant to raise questions about their theoretical import. Nonetheless, with the use of these folk concepts, however inconsistent in their application, few people would deny that Anderson has produced some powerful new insights with his research.

Indeed, one of the effects of living in neighborhoods that are racially segregated is exposure to group-specific cultural frames, worldviews, orientations, habits, styles of behavior, as well as particular skills that emanate from patterns of racial exclusion. Some scholars describe these as 'non-dominant forms of cultural capital' (Carter 2003), which may not be conducive to facilitating social mobility in mainstream social institutions (Wilson, 2009). For example, in Anderson's Code of the Streets, some groups in the ghetto place a high value on "street smarts," the actions and behavior that keep them safe in high crime neighborhoods. Street smarts is an adaptation to living in unsafe areas. In this milieu, it is wise to keep to yourself and avoid eye contact with strangers. This frame of mind may also lead individuals to approach new situations with a certain level of mistrust or skepticism. While this is smart and logical in certain contexts, the same orientation may inhibit the formation of valuable social ties in other settings. Moreover, this orientation may in 
some cases influence the often racially-tinged assessments of employers in job interviews and create perceptions that that they are undesirable job candidates (Pager and Shepherd 2008, Wilson, 1996, and Kirschenman and Neckerman 1991).

Anderson's "code of the street" is an informal but explicit set of rules developed to regulate violence and govern interpersonal public behavior in ghetto neighborhoods where residents often view crime as high and police protection as low. The issue of respect is at the root of the Code, argues Anderson. In a context of limited opportunities for success and self-actualization, some residents in ghetto neighborhoods, most notably young black males, develop alternative ways to gain respect that emphasizes manly pride, ranging from talking the right way and wearing brand-name clothing to have the "right look," to developing attitudes of asserting their power or strength toward neighbors. Anderson points out, however, all the residents of these troubled neighborhoods are affected by the code of the streets, especially young people, who are drawn into this cultural frame both on the streets and in the schools and frequently adopt "street" behavior as a form of self defense. As Anderson argues, "the code of the street is actually a cultural adaptation to a profound lack of faith in the police and the judicial system-and in others who would champion one's personal security" (Anderson, 1999:34). 
If the issue is explaining ghetto responses to chronic subordination, Anderson provides a powerful argument within the context of validation, regardless of his use of folk terms to describe some patterns of behavior. Indeed, it would be difficult to defend the view that "the code of the street" cannot be seen as both a descriptive and analytic construct, as Anderson uses it, in the context of validation.

As we reflect on Anderson arguments on the merits of inductive theory in ethnographic research, we cannot think of any notable ethnography that is not in some way inductive. In many respects, some aspects of ethnography research, such as participant observation, are almost by definition inductive, as researchers try to make sense of new findings uncovered in the field. Moreover, a number of theoretically informed ethnographies reflect both a deductive and inductive approach. Two of the most explicit examples are Wilson and Taub's study, There Goes the Neighborhood (2006) and Mario Small's, Villa Victoria (2004). A crucial theoretical question that Wilson and Taub raised in their ethnographic study of four working/lower middle class neighborhood in Chicago is to what extent were their findings consistent with the assumptions of Albert Hirschman's theory of exit, voice and loyalty (Hirschman, 1970)? Their findings led them to augment these theoretical formulations in development of a broader 
theory of the social organization of neighborhoods that integrated proposition from Hirschman's theory with theoretical arguments, based on their data, that associate the strength of neighborhood social organization with neighborhood ethnic stability and change. Likewise, in his excellent book Villa Victoria, Mario Small, set out to examine theoretical assumptions about poor neighborhoods and social capital, by conducting research in a poor Puerto Rican neighborhood in Boston. However, he ended up developing a more comprehensive theory of poverty and social capital based on his imaginative use and interpretation of ethnographic data he collected in the field. However, if Small and Wilson and Taub's studies represent an explicit integration of the deductive and inductive methods, Mitchell Duneier's book, Sidewalk, is a good example of a study that implicitly integrates inductive and deductive theoretical insights. As Duneire points out in his response to Wacquant, his approach is neither strictly deductive nor inductive. He describes his engagement with theories about public space and safety, including the theories Jane Jacobs and James Q. Wilson. Duneier does not seem to be arguing that theory is unimportant to him, as Wacquant seems to suggest. He is saying that Wacquant ignores the attention he does give to theory.

Using a doctor's analogy with the concept 'diagnostic ethnography,' Duneire points out that he engages in a variety of 
theoretical/sociological questions, some of which he discovered while conducting research on his site. He states, 'the idea of diagnostic ethnography is not that ethnography extracts a theory out of clinical data. Rather the idea is that the ethnographer comes to a site with the sociological equivalent of the doctor's medicine bag of diagnostic tools derived from already-existing sociological theory and uses these tools to generate a specific explanation of the 'symptoms' in the site' (Duneire, 2002: 1566).

Although both Anderson and Duneier argue that their work is theoretically informed, they are both critical of what they perceived as Wacquant's particular view of the role of theory in ethnography. Both seem to suggest that too much theory is conducive to interpretations that rely too heavily on structural determinism. In other words, both seem to suggest that Wacquant's "top down" approach would lead the ethnographer to 'subordinate the cultural complexity he or she finds in the field to that theory' (Anderson 202: 1534).

However, it is certainly not clear to us why Wacquant's arguments about theoretically informed research should necessarily lead one to rigidly interpret data through the lens of structural determinism. What Wacquant seems to be suggesting is that ethnographic work be theoretically informed, and his views are probably more consistent with a deductive theoretical approach. But, 
based on our review of his essay, there is nothing in his comments that would suggest that he does not see the value of inductive theoretical insights, whereby theoretical knowledge aids in the interpretation of new findings uncovered in the field.

This not to say that there are no pitfalls when one uses theory to guide research. Just as a strictly deductive approach could lead one to overlook important nuanced behavior not consistent with prior theoretical arguments, so too could an inductive approach result in an inappropriate use of certain theoretical insights to interpret new findings. But few scientific endeavors are free of errors. The extent to which work can withstand critical and prolonged scrutiny in the context of validation will be based in large measure on the researchers creative insights in the discovery and integration of empirical findings and theoretical ideals.

An important valuable aspect of Wacquant's critique of Anderson and Duneier is that it prompted the two researchers to make explicit the theoretical issues they believe are implicit in their research. We see this as positive, not as a defensive argument in support of their works, but in informing the reader of the subtle but important role that theory does in fact play in their research. We see their work as representing the logic of social inquiry, legitimately falling both within contexts of discovery and the context of validation. 
We have a different view of Newman's book, No Shame in My Game (1999). In response to Wacquant's critique about the theoretical basis of her study, Newman mainly defends her research on the grounds that "underclass theory" presented the urban poor as detached from the labor force, not subscribing to mainstream values, deviant, or otherwise outside the social norm. She explains that she then 'looked to see whether the unemployed were so separated from workers; whether welfare mothers and their kin were as far removed from the world of work as this theory asserted; whether role models were really absent from the ghetto; whether ghetto dwellers appreciate the role of education in later mobility; and whether "mainstream" models of behavior had really disappeared with the exodus of more affluent families' (Newman 2002: 1578).

There are major problems with her argument. The objective of the so-called "underclass theory" to which she refers was to make an argument about the structural forces that produced conditions of concentrated poverty, and related problems such as joblessness, and to examine the implications of these factors for inner-city residents. The arguments associated with "underclass theory" did not simply stipulate that people were not working or engaged in behavior associated with work. Rather the arguments attempted to provide theoretical explanations for why conditions in inner-city neighborhoods 
had changed over time and how social processes worked in those contexts resulted in increasing (i.e., not universal) rates of joblessness.

Accordingly, one is not refining or challenging those theories by simply describing supposedly contrary evidence showing that, indeed, many people in the inner city are working and subscribe to mainstream values. Unlike Anderson and Duneier, Newman is not explaining the social mechanisms or processes underlying observed social phenomena. To be sure, media coverage, public discussion and academic research transmuted the concepts from describing those who were economically marginalized by structural economic shifts to referring to entire communities that were inappropriately characterized primarily by their own attitudes and behaviors (Wilson, 1991).

To the extent that dominant popular conceptions view the urban poor as universally idle and rejecting mainstream values, etc, then by documenting the working poor who value hard work, Newman is indeed countering those stereotypes of the urban poor. However, that is not the same as challenging earlier theories which simultaneously recognize that a substantial proportion of the urban poor are regularly engaged in the urban labor market and put forth arguments that seek to explain certain changing conditions and social processes in the inner city that affect increasing concentrations of poverty and joblessness. 
Newman argues that, contrary to Wacquant, sociology should indeed address moral portraits of the poor. The critique made by Wacquant, however, is that Newman merely presents a moralistic view of the working poor, rather than analyzing moral depictions of them. Indeed, one can point to several important studies that analyze how moral constructions of the poor influence the formation of social policy (Katz 1989, Skocpol 1992). Newman suggests that challenging negative moral depictions of the poor is important for our goals (presumably to influence the discourse around policy reform). To be clear, public engagement with pressing political social issues should not be discounted, especially given the troubling terms of public discourse around the urban poor. This should not, however, be misleadingly conflated with contributing to a sociological explanation of the behavior and experiences of the poor. Newman's argument's seems more oriented toward the strategic framing of a political issue. We do not pass judgment on either objective in this discussion, but rather highlight the distinction and note that they are not always overlapping. In short, Newman is not adequately addressing theoretical issues consistent with the logic of inquiry, nor making a theoretical contribution in either an inductive or deductive sense to our understanding of the forces and processes that shape behavior and social outcomes 


\section{Conclusion}

We began this discussion by pointing out that scholars in the field have not seriously discussed the important issues that Loic Wacquant raised in his controversial review of the books by Anderson, Duneier, and Newman concerning the disconnnect between theory and ethnographic research. Despite the tone of Wacquant's review, we feel he made a contribution in raising important issues about the role of theory in ethnography. The responses to his review that address this issue, especially those by Anderson and Duneier, are also important because they help to broaden our understanding of how theory is used in ethnographic research, particularly the inductive theoretical approach. Ethnography has always been an important part of the sociological enterprise, and increasingly scholars are beginning to appreciate its role in the context of validation. In other words, it is no longer simply relegated to the context of discovery.

What we take from this exchange is that good ethnography is theory driven. And given the very nature of ethnographic research, it is likely to be much more reflective of inductive theoretical insights than those that are purely deductive. But we have also learned that in some ethnographic studies the theoretical insights are neither strictly deductive nor inductive, but represent a combination of both. We 
might even venture to say that arguably the most creative ethnography reflects this synthesis.

\section{References}

Anderson, Elijah (1999) Code of the Street: Decency, Violence, and the Moral Life of the Inner City. New York: W.W. Norton. (2002) 'The Ideologically Driven Critique.'

American Journal of Sociology 107(6):1533-50.

Burawoy, Michael (1979) Manufacturing Consent: Changes in the Labor Process Under Monopoly Capitalism. Chicago: University of Chicago Press.

Carter, Prudence L. (2003) '"Black" Cultural Capital, Status Positioning, and Schooling Conflicts for Low-Income African American Youth.' Social Problems 50(1):136-155.

Duneier, Mitchell (2002) 'What Kind of Combat Sport Is Sociology?' American Journal of Sociology 107(6):1551-76. (1999) Sidewalk. New York: Farrar, Straus \&

Giroux.

Gans, Herbert J. (1962) The Urban Villagers: Group and Class in the Life of Italian-Americans. New York: The Free Press

Hannerz, Ulf. (1969) Soulside: Inquiries into Ghetto Culture and Community. New York: Columbia University Press. 
Hirschman, Albert O. (1970) Exit, Voice, and Loyalty: Responses to Decline in Firms, Organizations, and State. Cambridge: Harvard University Press.

Jacobs, Jane (1961) The Death and Life of Great American Cities. New York: Random House.

Katz, Michael B. 1989. The Undeserving Poor: From the War on Poverty to the War on Welfare. New York: Pantheon Books.

Kirschenman, Jolene and Kathryn M. Neckerman (1991) '"We'd Love to Hire Them, But...": The Meaning of Race for Employers,' in Christopher Jencks and Paul E. Peterson (eds) The Urban Underclass, Washington, DC: Brookings Institution Press.

Newman, Katherine S. (1999) No Shame in My Game: The Working Poor in the Inner City. New York: Alfred A. Knopf and Russell Sage Foundation. (2002) 'No Shame: The View from the Left Bank,' American Journal of Sociology 107(6):1577-99. Pager, Devah and Hana Shepherd (2008) 'The Sociology of Discrimination: Racial Discrimination in Employment, Housing, Credit, and Consumer Markets.' Annual Review of Sociology 34: 181-209. 
Skocpol, Theda (1992) Protecting Soldiers and Mothers: The Political Origins of Social Policy in the United States. Cambridge, MA: The Belknap Press of Harvard University Press.

Small, Mario L. (2004) Villa Victoria: The Transformation of Social Capital in a Boston Barrio. Chicago: University of Chicago Press.

Suttles, Gerald (1970) The Social Order of the Slum: Ethnicity and Territory in the Inner City. Chicago: University of Chicago Press. Wacquant, Loic (2002) 'Scrutinizing the Street: Poverty, Morality, and the Pitfalls of Urban Ethnography,' American Journal of Sociology 107(6): 1468-1532.

Willer, David (1967) Scientific Sociology: Theory and Method. Englewood Cliffs, NJ: Prentice Hall, 1967.

Willis, Paul. (1981) Learning to Labor: How Working Class Kids Get Working Class Jobs. New York: Columbia University Press.

Wilson, William Julius (1987) The Truly Disadvantaged: The Inner City, the Underclass and Public Policy. Chicago: University of Chicago Press.

(1991) 'Studying Inner-City

Dislocations: The Challenge of Public Agenda Research,' American Sociological Review 56(1): 1-14.

(1996) When Work Disappears: The World of the New Urban Poor. New York: Alfred A. Knopf. 
(2009) More than Just Race: Being Black

and Poor in the Inner City. New York: W.W. Norton Press.

Wilson, William Julius and Richard P. Taub (2006) There Goes the Neighborhood: Racial, Ethnic and Class Conflict in Four Chicago Neighborhoods and Their Meaning for America. New York: Alfred A. Knopf. 